\title{
Intersubjetividade ou Solipsismo? Aporias da Teoria do Agir Comunicativo de Jürgen Habermas
}

\author{
João Paulo Bachur \\ Instituto Brasiliense de Direito Público (IDP), Brasília, DF, Brasil. E-mail: \\ joaopbachur@hotmail.com
}

\section{INTRODUÇÃO}

\begin{abstract}
A teoria do agir comunicativo de Jürgen Habermas é certamente uma das iniciativas teóricas de maior envergadura do século XX, não apenas por incorporar a inflexão política relativa à crise do Estado de Bem-Estar e da social-democracia europeia como pano de fundo para a construção de uma teoria sociológica da ação, mas também, e sobretudo, por incluir definitivamente linguagem e comunicação na pauta da teoria social, inclusive nos desdobramentos para a teoria do direito e da democracia.
\end{abstract}

A teoria habermasiana do discurso, originada nos estertores da Escola de Frankfurt, integra hoje o cânone da teoria social. Certos efeitos paradoxais típicos dos clássicos já se permitem vislumbrar: Habermas é muito frequentemente citado, muito facilmente criticado (por vezes até mesmo de maneira simplista), mas a articulação interna de sua construção conceitual já não ocupa o centro do debate na teoria sociológica. Em geral, parte-se do pressuposto de que a teoria do discurso está plenamente estabelecida, abrindo-se então espaço para uma opção entre duas alternativas mutuamente excludentes: de um lado, a tomada de partido em prol de um conceito normativo de racionalidade, de uma esfera pública livre de coerção, de uma democracia deliberativa sensível à sociedade civil etc.; de outro, a refutação com base em seu caráter idealista e utópico ${ }^{1}$. Entretanto, a questão central da teoria do agir comunicativo - a intersubjetividade - parece não ter sido equacio-

DADOS - Revista de Ciências Sociais, Rio de Janeiro, vol. 60, nํ2, 2017, pp. 541 a 575. 
nada por Habermas a contento e justificaria, ainda hoje, uma discussão mais detida e verticalizada, do ponto de vista da construção teórica desse conceito. Nessa direção, o artigo procura investigar os fundamentos teóricos da intersubjetividade na teoria do discurso.

Sinteticamente, a hipótese de trabalho deste artigo poderia ser formulada da seguinte maneira: a intersubjetividade pretendida pela teoria do agir comunicativo é solapada pelo subjetivismo monológico de suas próprias premissas. Habermas reconhece, com razão, a necessidade de enfrentar o problema da linguagem e da comunicação do ponto de vista da teoria social. A questão toda é que Habermas não oferece uma alternativa efetivamente comunicativa ou discursiva para solucionar o desafio da intersubjetividade tal como ele mesmo o formula. Em outras palavras, há um solipsismo constitutivo, intrínseco à teoria do agir comunicativo, que não apenas nega a intersubjetividade (o aspecto propriamente comunicativo da teoria do discurso), mas que, no limite, compromete também o modelo de legitimação deliberativa do direito e da democracia. Esta é a linha argumentativa do artigo.

Habermas tem sido tão intensamente debatido nas últimas décadas no Brasil (cf. e.g. Avritzer, 1999; Neves, 2006; Nobre et al., 2008; Nobre e Repa, 2012), que parece razoável supor um patamar mínimo de compreensão do conjunto de sua obra teórica, eximindo-nos assim de apresentações conceituais introdutórias. Não obstante, uma distinção fundamental da teoria do agir comunicativo tem de ser aqui mencionada, pois toda a argumentação deste artigo se articula em torno dela, qual seja, a distinção entre agir comunicativo (kommunikatives Handeln) e discurso (Diskurs). Essa distinção deriva da característica fundamental da linguagem - a reflexividade. Habermas distingue duas modalidades de emprego da linguagem: (i) o agir comunicativo de um lado, caracterizado pelo conjunto das interações cotidianas que fluem de maneira razoavelmente não problemática e que compõem o chamado mundo da vida; e (ii) o discurso, caracterizado pela coordenação entre os interactantes no que concerne à interpretação da situação fática por eles compartilhada (cf. Habermas, 1971:115; 1981; e 1984). Enquanto o agir comunicativo cotidiano está plenamente inserido no mundo da vida, transcorrendo de forma a viabilizar a troca de informações e a execução concreta de cursos de ação individuais, o discurso interrompe esse fluxo a fim de neutralizar restrições objetivas (i.e., não linguísticas) e virtualizar a constante pressão sobre os atores para agir (Handlungszwang). Com isso, os interactantes podem se deixar envol- 
ver pelo discurso, definindo seus respectivos planos de ação de maneira recíproca e determinando seus fins individuais de acordo com uma regra de consenso quanto ao sentido da situação por eles vivenciada de maneira compartilhada, independentemente de tal consenso existir previamente ao discurso ou de ser ele negociado discursivamente (Habermas, 1983:144).

Essa distinção entre agir comunicativo e discurso, entre uso ordinário e extraordinário da linguagem, entre rotina e exceção, parece ser o núcleo da teoria social de Habermas, pois está relacionada à reflexividade da linguagem. É característica essencial da linguagem a possibilidade de que um recorte temático qualquer seja destacado do pano de fundo não problematizado do mundo da vida para ser submetido a um tratamento discursivo diferenciado: a linguagem somente pode ser tematizada por meio de si própria. Pensemos, por exemplo, em palavras como "liberdade", "igualdade" ou "justiça", utilizadas rotineiramente nos meios de comunicação de massa, em aulas e seminários universitários, nas rotinas decisórias oficiais, nas conversas diárias das pessoas etc. É claramente possível distinguir os momentos em que tais palavras são empregadas de maneira não problemática e os momentos em que elas são problematizadas discursivamente (e.g., um debate parlamentar sobre aborto e a liberdade da mulher sobre seu próprio corpo). Num caso, tem-se agir comunicativo, no outro, discurso. Aí está a reflexividade típica da linguagem: no discurso, ela toma a si mesma como objeto. Isso vale tanto para as unidades comunicativas de menor escala quanto para macroprocessos sociais. A reflexividade da linguagem é, em última análise, o fundamento do discurso e, por isso, tem de ser praticada de maneira radicalmente intersubjetiva: a troca automática de informações tem de ser suspensa em favor de uma deliberação dialógica. E isso de maneira radicalmente intersubjetiva.

A argumentação desenvolvida a seguir pretende demonstrar porque essa tarefa não é levada a termo por Habermas. Para tanto, veremos na seção intitulada "Da Esfera Pública à Democracia Deliberativa", como o problema da intersubjetividade emerge no percurso entre a reconstrução histórica da esfera pública burguesa e sua projeção como modelo para o paradigma deliberativo do direito e da democracia. A esfera pública burguesa do século XVIII é o paradigma histórico e típicoideal para a reflexividade da linguagem, pois ali tem lugar a problematização discursiva de recortes do mundo da vida. A democracia deliberativa é a projeção mais acabada disso, pois exige que a legislação

DADOS - Revista de Ciências Sociais, Rio de Janeiro, vol. 60, nº 2, 2017 
oficial se reporte à formação espontânea da vontade coletiva em fóruns capazes de problematizar recortes do mundo da vida. Por conseguinte, e de maneira coerente com o postulado da reflexividade da linguagem, o discurso tem de ser capaz de fundar-se a si mesmo. Essa exigência põe o problema da distinção entre o verdadeiro e o falso consenso, o que exige de Habermas a formulação da situação ideal de fala, conforme a seção "A Situação Ideal de Fala como Fundamento do Entendimento Linguístico", deste artigo. Essa situação é constitutivamente aporética, pois assenta o discurso (intersubjetivo, dialógico) na pressuposição da situação ideal de fala - e toda pressuposição é, em última instância, uma operação monológica do sujeito. Para contornar esse paradoxo, Habermas tem de formular uma regra de sinceridade, segundo a qual não pode haver discrepância entre uma sentença linguística, seu significado discursivo e a intenção subjetiva dos participantes do discurso (ver a seção "A Regra da Sinceridade"). Se não há possibilidades de discrepância, a busca pelo entendimento se torna na verdade tautológica: os interactantes alcançam o consenso porque, à luz da impossibilidade de desvios comunicativos, buscam o consenso. Mas, para isso, é preciso que os interactantes estejam, de antemão, moralmente comprometidos com a busca pelo consenso, o que somente pode ser assegurado em sua convicção íntima, monológica (seção "O Comprometimento Íntimo com a Busca pelo Consenso"). Esses problemas comprometem o modelo deliberativo da democracia, pois supõem uma simetria plena entre os participantes no discurso, quando a democracia é definida justamente pela assimetria histórica entre eles, conforme veremos na seção "Simetria Discursiva e Deliberação Democrática" mais adiante. Se a democracia pode ser definida como a junção entre o arranjo político institucional do século XIX e a pauta social herdada do século XX, então seu tema central é a assimetria material entre pessoas e grupos. A suposição da simetria discursiva aplaina essas discrepâncias e finda por esvaziar de sentido justamente o principal instrumento de que dispõem os modernos Estados de direito para visibilizar e discutir desigualdades materiais.

\section{DA ESFERA PÚBLICA À DEMOCRACIA DELIBERATIVA}

De maneira geral, o percurso teórico de Habermas pode ser caracterizado por uma espécie de "oco" institucional, por assim dizer. Partindo pela investigação da esfera pública e culminando em uma teoria deliberativa do direito e da democracia, a Teoria do agir comunicativo pode ser vista como um intervalo, um parêntese nas preocupações essencial- 
mente institucionais de Habermas. Com efeito, o período de composição da Teoria do agir comunicativo é um mergulho na concepção da "situação ideal de fala" (ideale Sprechsituation), essencialmente não institucional, e que funciona, em última análise, como fundamento do discurso orientado ao entendimento linguístico (Habermas, 1984). Ou seja, entre a análise histórica de uma instituição típica do mundo burguês e a defesa de um modelo deliberativo-procedimental do direito e da democracia, i.e., entre duas extremidades claramente institucionais de sua evolução teórica, Habermas incrusta uma concepção essencialmente anti-institucional da linguagem. Longe de ser apenas uma oscilação na construção teórica, trata-se aí do problema central para a noção de intersubjetividade, como ainda veremos em detalhe. Vejamos inicialmente como essa lacuna institucional se abre.

Em sua tese de habilitação, o clássico Mudança Estrutural da Esfera Pública (1962), Habermas investiga a transformação discursiva que inaugura o mundo burguês, qual seja, a institucionalização da esfera pública como instância de crítica política. A reunião de pessoas privadas em torno de um tema sofre uma alteração essencial quando essa reunião assume caráter público, quando ela deixa de se voltar para si mesma e passa a se voltar para o exterior. A constituição do público é o momento em que o indivíduo se forma historicamente como sujeito político (Habermas, 1962:86). No clássico trabalho de Reinhart Koselleck, a esfera pública aparece como uma espécie de "tribunal moral" perante o qual o poder político do Estado tem de se legitimar continuamente, o que se revela, no limite, uma tarefa aporética - não obstante a política tenha se diferenciado e se autonomizado em relação à moral, remanesce uma necessidade de justificação do poder político perante o público (Koselleck, 1959:8-9). Em Habermas, a esfera pública perde essa determinação estritamente negativa ao deixar de ser um âmbito para discussões estéticas e literárias e assumir uma função especificamente política. Ela deixa de ser o outro da política para se tornar justamente a instância política por excelência, o locus essencial da formação da vontade coletiva. Essa é a mudança - que Habermas denomina estrutural da esfera pública.

Na origem, a esfera pública não surge como espaço imediatamente político, mas como ambiente para a discussão estética, especialmente a literária. Os salões e cafés ampliaram o círculo doméstico, em que rudimentos de argumentação pública foram originalmente desenvolvidos para a discussão de obras de arte no ambiente privado. A esfera públi-

DADOS - Revista de Ciências Sociais, Rio de Janeiro, vol. 60, nº 2, 2017 
ca literária é assim o campo de treinamento da deliberação pública (Habermas, 1962:88). Com efeito,

museus, assim como concertos e peças de teatro, institucionalizam o julgamento leigo da arte: a discussão é o meio de apropriação estética. Os inúmeros panfletos de crítica ou apologia da teoria estética dominante se conectam com as conversas nos salões e são assim absorvidos crítica estética como conversação (idem:102-103)².

O essencial é a capacidade de raciocínio e argumentação em público (öffentliches Räsonnement), ou seja, o fato de que pessoas privadas adquiriram, de maneira relativamente igualitária, a habilidade de sopesar argumentos apresentados diante de um público, acatando-os ou refutando-os com novos e próprios argumentos: "a discussão em público pressupõe a problematização de âmbitos que até então não eram considerados questionáveis" (Habermas, 1962:97). É claro que, nesse ponto, Habermas estiliza a esfera pública burguesa, generalizando a partir dela um modelo de sociabilidade tomado como universal (cf. Luhmann, 1980; Garnham, 1992:365; Tucker, 1996). Não obstante, os traços fundamentais da teoria do agir comunicativo já se permitem notar: a capacidade de destacar um tema para o debate público, isolando-o do pano de fundo não problematizado do cotidiano, irá se refletir posteriormente na distinção entre discurso e mundo da vida. Aí reside a reflexividade da linguagem - a possibilidade de recortar um âmbito discursivo específico e tematizá-lo para além das rotinas comunicativas usuais.

Mas a esfera pública burguesa, nascida da politização dos fóruns de discussão estética, passa por uma nova mudança estrutural com a consolidação do Estado de Bem-Estar nas democracias industrializadas da Europa do pós-guerra. Se a Revolução Francesa desencadeou uma onda de politização da esfera pública burguesa, fazendo com que círculos de discussão literária passem a julgar a legitimidade do poder político, a esfera pública burguesa se despolitiza com o avanço do paradigma institucional do welfare state e da correlata consolidação de uma sociedade do consumo de massa. O Estado-providência e o consumo generalizado transformam mais uma vez a esfera pública: ela perde sua determinação essencialmente crítica e pode ser relativamente instrumentalizada em prol das necessidades legitimatórias do aparato estatal (Habermas, 1962:325). Nesse momento, o diagnóstico habermasiano converge com a crítica frankfurtiana à indústria cultural (Horkheimer e Adorno, 1947). A despeito desse diagnóstico crítico, 
que, diga-se de passagem, era um lugar comum da sociologia dos anos 1960, Habermas vê na esfera pública - compreendida como instituição fundante da democracia liberal - uma força política positiva, capaz de engendrar a vontade política livre e, com isso, renovar a tarefa de legitimação do poder no contexto da crise do Estado de Bem-Estar (Habermas, 1973). Essa tarefa aponta para uma renovação discursiva da teoria da democracia, apoiada em um modelo procedimental de esfera pública como alternativa capaz de encontrar novas fontes de legitimidade (Habermas, 1962:337; 1985; 1992; 1996:283 ss.). A tarefa formulada em Mudança Estrutural da Esfera Pública (a hipótese de que a esfera pública poderia renovar a legitimação política) tem seu fecho no modelo de democracia deliberativa defendido em Faticidade e validade, a outra extremidade institucional da teoria do discurso (Shelly, 1993; Markell, 1997).

O modelo de uma teoria deliberativa do direito, em que a legitimidade da legislação oficial deriva de processos espontâneos de formação da vontade política (Habermas, 1992), é a resposta de Habermas para críticas que acusavam um déficit institucional em sua teoria do discurso (e.g. Luhmann, 1971:329 ss.). Desde então a questão da institucionalização ganhou centralidade crescente na evolução teórica de Habermas, pois era preciso demonstrar como o discurso engendrado de forma livre se materializaria nos processos concretos de produção legislativa. Era preciso conceber uma espécie de barreira institucional às tendências de colonização do mundo da vida pelos sistemas da economia de mercado e do aparato estatal (Habermas, 1981, v. 2:489 ss.; 1985:390 ss.). Ou seja: “O princípio do discurso somente poderá assumir a forma de um princípio democrático se ele passar por uma institucionalização jurídica, atribuindo, por sua vez, força legitimatória ao processo de produção do direito" (Habermas, 1992:154).

O conhecido princípio do discurso assevera que somente podem ser válidas aquelas normas de conduta que poderiam ser acatadas, por meio de uma argumentação racional, por todos os potenciais sujeitos afetados por elas (Habermas, 1992:138). A questão toda é fazer com que essa forma de legitimação perpasse processos institucionais reais. O discurso tem de fundamentar a legislação. No contexto da evolução de Habermas, Faticidade e validade consolida justamente tal virada institucional: trata-se de aproveitar o potencial de redes comunicativas formadas espontaneamente para pôr em prática a deliberação pública conduzida segundo a premissa (contrafática) da situação ideal de fala,

DADOS - Revista de Ciências Sociais, Rio de Janeiro, vol. 60, nº 2, 2017 
em que somente a força do melhor argumento é capaz de engendrar o convencimento: "a teoria do discurso não torna a realização da política deliberativa dependente de uma cidadania capaz de agir coletivamente, de uma espécie de cidadão coletivo, mas da institucionalização de seus respectivos procedimentos" (Habermas, 1996:287; ênfase no original) ${ }^{3}$. Ou seja, a crítica que simplesmente tacha de "idealista" a versão habermasiana de uma teoria deliberativa do direito e da democracia perde de vista que Habermas se ocupa, de fato, dos processos concretos da democracia parlamentar e da maneira pela qual tais processos, mesmo que relativamente contaminados pela barganha política, ainda permitam concretizar o princípio do discurso no interior das instituições democráticas reais.

Como ainda veremos, não é o idealismo que compromete, em primeira linha, o projeto habermasiano de uma democracia deliberativa conduzida pela força do melhor argumento, mas a própria construção teórica que serve de pano de fundo para a conversão do princípio do discurso em uma diretriz institucional para as democracias reais, qual seja, a intersubjetividade compreendida a partir da situação ideal de fala, objeto da próxima seção. Vejamos antes disso como Habermas procura preservar um núcleo comunicativo capaz de produzir a vontade política segundo as regras do discurso livremente engendrado frente às pressões colonizadoras da burocracia estatal e da economia de mercado.

Para tanto, Habermas apresenta um "sistema de eclusas" (1992:429 ss.). O sistema político permite distinguir o centro da periferia do sistema, de forma que a relação entre esses dois âmbitos seja estruturada por um sistema de eclusas, quer dizer, por um sistema de duplas portas que prevê dois modos para lidar com os problemas do sistema político: o centro do sistema (administração pública, governo, tribunais, órgãos legislativos e instituições parlamentares, tais como concorrência partidária e eleições livres) dispõe de competências formalmente estabelecidas para a tomada de decisões, com diferentes graus de sensibilidade e efetividade. Por outro lado, a periferia se caracteriza por grupos de interesse mais ou menos organizados (associações, organizações culturais e filantrópicas, ONGs, igrejas etc.), que detêm níveis diferenciados de acesso ao centro. Esses públicos formadores de opinião fornecem aportes comunicativos informais ao centro do sistema político e compõem a infraestrutura da sociedade civil organizada. Por óbvio, Habermas não imagina que dinheiro e poder não exerceriam aqui influência alguma, considerando a importância dos meios de comunica- 
ção de massa na veiculação, por meio dos quais a sociedade civil organizada tem de se manifestar. Ele argumenta, contudo, que tais meios de comunicação, no que diz respeito a sua conexão com o dinheiro e o poder, não são suficientes para estruturar um discurso - no sentido da teoria do agir comunicativo, i.e., como discurso apoiado na força do melhor argumento, a partir do qual uma decisão política possa vir a ser considerada legítima. O reconhecimento de que o poder circula também na esfera pública e que sua influência na formação de pontos de vista é, em certa medida, incontrolável, não é suficiente para bloquear a função crítica da esfera pública; isso não implica a rejeição automática da tese de que a "comunicação pública pode se regenerar espontaneamente a partir de fontes do mundo da vida" (Habermas, 1962:28; ênfase no original).

O importante é que essa esfera pública fragmentada se agrupe espontaneamente: "No bojo de um arcabouço de direitos fundamentais assegurados constitucionalmente, as estruturas de uma esfera pública pluralista são formadas de maneira mais ou menos espontânea" (Habermas, 1992:373). Tais redes comunicativas configuram uma "intersubjetividade de nível superior" presente na formação não coercitiva da vontade política, que funcionam como arenas para a formação do consenso. Nelas pode ter lugar a argumentação racional, de forma que a comunicação assim produzida pode ser considerada livre - e, nessa medida, capaz de motivar um processo legislativo racional:

O fluxo comunicativo entre a formação pública da vontade, as instituições eleitorais e as decisões parlamentares deve assegurar que o poder comunicativamente gerado e a influência da esfera pública sobre a produção legislativa seja convertido no poder formal capaz de ser empregado administrativamente" (Habermas, 1992:362-363).

Ou seja,

[...] para serem consideradas legítimas, decisões vinculantes têm de ser conduzidas por fluxos comunicativos originados da periferia do sistema político, os quais têm de passar pelas eclusas dos procedimentos democráticos, típicos do Estado de direito, ao penetrarem no complexo institucional parlamentar e judicial (e, conforme o caso, ao penetrarem também na administração pública) (idem:432).

Isto é, a comunicação livre produzida nas associações espontâneas da esfera pública tem de percorrer os canais institucionais que separam a

DADOS - Revista de Ciências Sociais, Rio de Janeiro, vol. 60, n² 2, 2017 
periferia do centro do sistema político, até se materializar em uma decisão oficial: "uma lei só é válida, em sentido moral, quando ela, da perspectiva de cada um, puder ser aceita por todos" (Habermas, 1996:46). O poder comunicativo informal, espontâneo, tem de se converter em poder político formal, cogente. Somente no curso desse processo as decisões políticas podem ser consideradas legítimas.

Esse processo de institucionalização do discurso revela exatamente aquela estrutura reflexiva típica da linguagem: a formação espontânea da vontade coletiva na esfera pública tem de ser forte o suficiente para abrir uma exceção nas rotinas decisórias do poder político formal, contaminando-as. Trata-se aqui da capacidade, por parte do centro do sistema político, de se manter aberto aos aportes comunicativos oriundos da periferia (Habermas, 1992:432-433). Para que o discurso produzido de maneira não coercitiva possa se institucionalizar, os fluxos comunicativos oriundos da periferia têm de perturbar o centro; eles precisam exercer considerável pressão sobre o centro, de forma que as rotinas decisórias convencionais fiquem abaladas, demandando um mecanismo excepcional para a solução dos problemas colocados em debate:

As expectativas se dirigem à capacidade da periferia de perceber problemas que atingem a sociedade como um todo, interpretá-los e torná-los objeto de atenção no debate público de maneira inovadora. Essas expectativas, exigentes, somente podem ser atendidas pela periferia na medida em que as redes comunicativas não institucionalizadas da esfera pública permitam processos mais ou menos espontâneos de formação da vontade coletiva (ibidem:434; ênfase no original).

A questão toda é: como fazer isso?

O discurso precisa executar um duplo movimento: inicialmente, ele tem de imunizar a linguagem frente às limitações e pressões estratégicas vigentes na comunicação cotidiana do mundo da vida. O discurso racional tem necessariamente de se servir da linguagem comum, destacando-a das pressuposições não problematizadas vigentes nas interações cotidianas e corriqueiras do mundo da vida. Em seguida, o consenso racional obtido discursivamente tem de se institucionalizar como legislação oficial. De certa maneira, a linguagem cotidiana do mundo da vida é plenamente "institucionalizada" ou institucionalmente saturada; ela conta com a adesão prévia e não problematizada de todos os interactantes, pois, do contrário não seria possível obter um mundo da vida compartilhado por todos (Berger e Luckmann, 
1966; Luckmann e Schütz, 1975). O fluxo de interações cotidianas não pode refletir sobre si mesmo a cada instante, sob pena de inviabilizar o entendimento e a continuidade da comunicação. O discurso, contudo, tem de se erguer a partir desse pano de fundo e permitir uma problematização linguística mais profunda, para daí então retornar como legislação. A teoria do discurso exige inicialmente a "desinstitucionalização" da linguagem, a fim de que o consenso racional possa ser livremente obtido no bojo de uma esfera pública espontaneamente articulada, para que tal consenso seja então "reinstitucionalizado" no fluxo de uma decisão formal, tomada de acordo com os filtros do procedimento democrático parlamentar ${ }^{4}$.

O discurso, idealizado a partir do estudo histórico da esfera pública burguesa, tem de se "desinstitucionalizar" como comunicação livre para se "reinstitucionalizar" como poder político formal - o miolo, entretanto, remanesce a cargo de uma categoria anti-institucional, a situação ideal de fala. Para que as duas extremidades institucionais da teoria do discurso sejam articuladas a contento, a situação ideal de fala tem de ser radical e inquestionavelmente intersubjetiva, dialógica. É aí, porém, que os problemas começam a aparecer.

\section{A SITUAÇÃO IDEAL DE FALA COMO FUNDAMENTO DO ENTENDIMENTO LINGUÍSTICO}

Inicialmente é preciso afastar alguns mal-entendidos frequentes, segundo os quais, para Habermas, toda e qualquer interação estaria voltada à obtenção do consenso, como se não houvesse dissenso. Habermas é muito claro ao afirmar que a maioria das interações cotidianas não busca o entendimento linguístico, da mesma forma como nega que o consenso seja meramente um ideal regulador da prática comunicativa cotidiana; mais ainda, ele nega mesmo que o agir comunicativo escape em última instância a uma macroestrutura teleológica, desprovida de orientação finalística: o mundo da vida é repleto de interações estratégicas, o consenso empiricamente verificável pode ser estabelecido, de fato, por quaisquer motivos (dentre eles a persuasão não linguística ou mesmo a força), e a busca do consenso em uma argumentação racional tem de seguir, em última instância, uma orientação finalística - agir comunicativo e agir estratégico não deixam de apresentar uma estrutura comum baseada na adequação entre meios e fins (cf. Habermas, 1980a:553; 1981, v. 1:150-151 e 388; 1992:18; 1982). As críti-

DADOS - Revista de Ciências Sociais, Rio de Janeiro, vol. 60, nº 2, 2017 
cas apoiadas nesses pontos não apenas contornam a letra do texto habermasiano, elas remanescem na superfície da teoria do discurso.

Evidentemente, Habermas tem plena consciência de que a rotina dos órgãos parlamentares reais tende muito mais para o agir estratégico do que para a busca do entendimento linguístico, de forma que a realização do princípio do discurso não pode ser de fato identificada na vida parlamentar tal como ela se realiza concretamente. De um ponto de vista empírico, a questão somente pode ser respondida praticamente: apenas a prática política concreta pode encontrar maneiras alternativas de sobrecarregar o centro do sistema político. No plano teórico, porém, tem de permanecer possível distinguir e observar analiticamente a transformação da comunicação espontânea e não institucional em legislação oficial. Sem isso, como saber se uma determinada lei é fruto da formação espontânea da vontade coletiva de uma esfera pública livre ou se ela é apenas o subproduto das rotinas decisórias tradicionais da burocracia parlamentar e governamental? Essa questão está relacionada a um problema teórico de fundo: como distinguir o consenso obtido discursivamente em uma argumentação racional e dialógica da mera coincidência fática de opiniões, seja ela casual ou motivada pelo agir estratégico? Isto é, como distinguir o verdadeiro consenso do falso consenso?

A questão é importante, e não do ponto de vista de um observador externo não participante do discurso, um observador de segunda ordem, seria possível dizer (Luhmann, 1995). Habermas se previne da crítica relativa ao observador externo com o argumento de que ele introduz uma dimensão objetivista e monológica, quando o discurso tem necessariamente de ser julgado única e exclusivamente de um ponto de vista intersubjetivo (Habermas, 1985:426 ss.). A refutação da crítica fundada no observador externo, da qual não nos ocuparemos aqui, exige que, admitindo as premissas das quais parte Habermas, notadamente a premissa da reflexividade da linguagem, o discurso seja capaz de se autofundar: seu fundamento tem de ser intersubjetivo, dialógico. Não vale, para o discurso, a pressuposição de um último reduto monológico; é dizer, o discurso não pode ser derivado de nada exterior a ele mesmo. Daí, portanto, a impossibilidade de distinguir entre o verdadeiro e o falso consenso de um ponto de vista exterior ao discurso. Essa diferenciação tem de ser produzida internamente ao discurso: só os participantes do discurso (e não um observador externo) são capazes de aferir a autenticidade do consenso obtido discursivamente. Para o discurso 
são necessários no mínimo dois interactantes, claro; como então assegurar que ambos tenham certeza de que estão engajados na busca por um consenso verdadeiro? Nesse passo, é preciso investigar como Habermas constrói a situação ideal de fala.

Confrontado com essa necessidade teórica, Habermas contorna o problema afirmando que

nós pressupomos reciprocamente uma situação ideal de fala em cada discurso. A situação ideal de fala é caracterizada pelo fato de que cada consenso (buscado segundo as condições dessa situação ideal de fala) pode valer per se como consenso verdadeiro" (Habermas, 1971:136; ênfase no original).

A situação ideal de fala elide deformações sistemáticas da comunicação ao estabelecer (idealmente) a simetria estrita de chances comunicativas entre os interactantes: o discurso pode ser reaberto a qualquer momento, perpetuando-se entre réplicas e tréplicas infinitas, sem levar em consideração aspectos temporais ou constrições não linguísticas. Com isso, opera-se a passagem para o "agir comunicativo puro", em que a situação ideal de fala funciona como uma "ficção operacionalmente efetiva no processo comunicativo" (Habermas, 1972:180).

Antes de reproduzir a crítica corriqueira de que, ao fim e ao cabo, a teoria do discurso é idealista, é preciso reconhecer que a situação ideal de fala funciona inicialmente como elemento crítico para isolar um determinado recorte do mundo da vida, a fim de submetê-lo a uma argumentação racional. Sem isso, a reflexividade da linguagem seria aplainada em um mundo unidimensional. Nota-se, no entanto, um paradoxo de difícil solução: como um ideal qualquer pode ser "reciprocamente pressuposto"? Como pode um ideal ser pressuposto ao mesmo tempo - necessariamente ao mesmo tempo - por no mínimo duas pessoas?

A solução clássica da filosofia para esse problema é o imperativo categórico de Kant. Mas Habermas refuta expressamente essa via como solução para o problema da situação ideal de fala, pois a pressuposição de condições transcendentais para o discurso remanesceria uma alternativa monológica. Não obstante Habermas reconheça adotar uma forma de "republicanismo kantiano", assumindo Kant como modelo para sua ética do discurso e sua teoria do direito (Habermas, 1996:8; 1992:109 ss.), ele rebate a crítica segundo a qual a teoria do agir comu-

DADOS - Revista de Ciências Sociais, Rio de Janeiro, vol. 60, nº 2, 2017 
nicativo seria uma atualização do imperativo categórico kantiano inspirada pela teoria da linguagem, mesmo quando ele próprio admite. Em seus termos, o teste de universalização do imperativo categórico kantiano é realizado de maneira monológica, pois o sujeito universaliza as regras de conduta que, para ele, são tidas como máximas de conduta. O discurso, ao contrário, seria dialógico de saída:

De fato, a aplicação reflexiva [i.e., dialógica] do teste de universalização exige uma situação de consulta aos demais, na qual é indispensável que cada um adote a perspectiva do outro, testando assim se uma norma jurídica, da perspectiva de cada um, pode ser desejável por todos. Essa é a situação do discurso racional orientado ao consenso, no qual todos aqueles submetidos à norma em questão tomam parte (Habermas, 1996:48-49).

A única solução para o problema da pressuposição recíproca estaria em admitir que o próprio discurso pode verificar as premissas nas quais ele se baseia, ou seja, de que o discurso tem de ser construído comunicativamente (no trecho citado, o "teste de universalização exige uma situação de consulta aos demais"). Isso exigiria, no entanto, pensar alguma forma de transição entre a agir comunicativo e o discurso, e não a oposição diametral entre um e outro - a não ser que, de saída e automaticamente, todos já estivessem de antemão comprometidos com a busca pelo entendimento linguístico. Eis então o papel da pressuposição da situação ideal de fala.

Na verdade, Habermas desfaz a alternativa entre o verdadeiro e o falso consenso porque, no discurso, os participantes pressupõem reciprocamente a situação ideal de fala - que, nessa medida, orienta o comportamento dos interactantes, de forma que todo consenso resultante será autêntico. A dificuldade de distinguir o verdadeiro consenso do falso é assim contornada, sem que com isso ela venha a ser teoricamente solucionada: se é a pressuposição recíproca da situação ideal de fala que assegura a autenticidade do consenso, então o entendimento linguístico não pode ser testado comunicativamente; i.e., o consenso é, em última instância, incomunicável - uma consequência dificilmente compatível com as premissas da teoria do agir comunicativo (Wenzel e Hochmuth, 1989). Se a situação ideal de fala fosse construída de forma verdadeiramente intersubjetiva, a reciprocidade dos interactantes teria de ser acessível discursivamente, isto é, ela deveria poder ser comunicativamente testada - e, nessa medida, refutada, reforçada ou reconstruída. Mas, como o discurso tem de fundar a si mesmo, radicalmente, ele não 
pode ser derivado da comunicação cotidiana. Nesse ponto, acentua-se a aporia constitutiva da teoria do discurso. De um lado, a situação ideal de fala, "reciprocamente pressuposta", não chega a ser um fenômeno empírico ou um modelo normativo orientador das interações concretas (como vimos, Habermas se socorre de uma formulação um tanto mística ao definir a situação ideal de fala como "ficção operacionalmente efetiva no processo comunicativo"). Para ser verdadeiramente reflexiva, a situação ideal de fala tem de ser necessariamente recíproca: não pode ser imputada exclusivamente ao falante ou ao ouvinte; ela teria de ser uma construção discursiva. A não ser que fosse possível identificar uma instância social capaz de estabilizar a situação ideal de fala - o que significaria, em alguma medida, institucionalizá-la, contrariando sua característica essencial, qual seja, a simetria ideal entre os interactantes - a pressuposição tem de remanescer a operação monológica de uma subjetividade.

O problema, como argumenta Sybille Krämer (e como reconhece o próprio Habermas, conforme se verá na próxima seção), é que os participantes do discurso nunca poderão saber de fato se estão engajados em um discurso autêntico ou meramente aparente (Krämer, 2001:86). Ou seja, o discurso não é discursivamente testável. Isso porque, no fundo, a situação ideal de fala se apoia em uma categoria monológica - a pressuposição por um sujeito racional. $\mathrm{O}$ argumento de que apenas o discurso decorrente da pressuposição recíproca da situação ideal de fala pode fundar um consenso racional é, ao fim e ao cabo, constitutivamente contraditório, quando não aporético. A aporia está na concepção da pressuposição como categoria supostamente discursiva. Com efeito, ao argumentar que os interactantes "pressupõem reciprocamente" a situação ideal de fala, essa pressuposição ressoa muito mais à duplicação formal de uma operação que, do ponto de vista filosófico, é constitutivamente monológica, do que ao diálogo propriamente dito, a despeito dos argumentos habermasianos contra a assimilação da situação ideal de fala ao imperativo categórico kantiano. A pressuposição da situação ideal de fala, ainda que recíproca, não se converte automaticamente em uma categoria discursiva. Na medida em que a situação ideal de fala é uma pressuposição, ela até poderia ser operada simultaneamente por mais de um sujeito - mas remanesceria uma operação subjetiva, inteiramente dependente da estrutura da subjetividade. E, sem o imperativo categórico e sem instâncias sociais que estabilizem a opção pelo discurso, não há garantias de que tal suposição ocorra para todos os participantes no discurso. O fundamento do dis-

DADOS - Revista de Ciências Sociais, Rio de Janeiro, vol. 60, nº 2, 2017 
curso, a situação ideal de fala, implica por isso recuar à estrutura monológica da subjetividade.

Mas será que Habermas, o mais influente teórico de fins do século XX, não teria se dado conta do problema? Por óbvio, a dificuldade não lhe passou despercebida. Mas o caminho escolhido para enfrentá-la acabou por acentuar o caráter monológico da teoria do agir comunicativo: considerando a impossibilidade de testar, discursivamente, uma pressuposição (pois isso exigiria alguma forma de assegurar, via comunicação, a sinceridade dos participantes, redundando em uma aporia filosófica semelhante ao paradoxo do mentiroso), Habermas finda por estabelecer um encadeamento linear e automático entre intenção, significado (Bedeutung) e afirmação (Aussage). Nesse passo, é preciso avaliar a reconstrução que Habermas faz da teoria dos atos de fala.

\section{A REGRA DA SINCERIDADE}

A teoria do agir comunicativo pretende integrar todas as funções da linguagem em uma releitura da teoria dos atos de fala de John Austin (e John Searle), conjugando-a com o interacionismo simbólico de George $\mathrm{H}$. Mead, a teoria dos jogos de linguagem de Wittgenstein, a teoria dos mundos de Popper, a teoria do símbolo de Karl Bühler e a pré-compreensão da tradição cultural de Gadamer. Evidentemente, essa reconstrução será aqui mencionada de maneira apenas esquemática.

Habermas identifica em Mead uma mudança de paradigma que lhe permitiria escapar à filosofia do sujeito, mas que não é devidamente aproveitada: Mead não explica como passar da coincidência entre sentidos atribuídos a um símbolo à capacidade de orientar a ação pelo entendimento recíproco. Habermas pretende suprir essa lacuna a partir do conceito de regra desenvolvido na teoria dos jogos de linguagem de Wittgenstein, pois no conceito de regra estão presentes tanto a identidade de símbolos compartilhados como a orientação da ação dos agentes comunicativos envolvidos. A interação simbolicamente mediada, quando apoiada em uma linguagem gramaticalmente estruturada, permite que as motivações e o repertório de ações seja reconstruído simbolicamente, nos termos de uma teoria pragmática formal da comunicação. Assim, a linguagem torna-se um meio de entendimento conforme o qual os agentes comunicativos interagem, tendo como pano de fundo o mundo da vida intuitivo e pré-compreendido, no sentido hermenêutico de Gadamer. O trânsito da interação simbólica à 
fala gramatical é feito por Habermas com a ajuda da teoria dos atos de fala de Austin. Os atos de fala podem ser: (i) locucionários, quando simplesmente expressam um estado de coisas; (ii) ilocucionários, quando o agente realiza uma ação dizendo algo; e (iii) perlocucionários, quando se busca causar um efeito no participante da interação comunicativa. Só é possível então configurar uma ação comunicativa através dos atos ilocucionários: somente eles têm a carga ambivalente que caracteriza uma proposição linguística fática, que põe pretensões de validade capazes de orientar a ação.

Segundo Habermas, a racionalidade de uma sentença linguística (Äußerung) reside na possibilidade de, por um lado, criticá-la e, por outro, fundamentá-la, sempre com recurso a argumentos. Os atos de fala ilocucionários tematizam pretensões de validade por meio das quais é possível criticar ou defender uma sentença linguística, assegurando-se assim um procedimento argumentativo dialógico. Toda sentença suscita quatro pretensões de validade, articuladas de acordo com a forma pela qual o falante se relaciona com o mundo, quais sejam: (i) a pretensão de compreensibilidade (Verständlichkeit), exigindo que o conteúdo proposicional de uma sentença expressa em uma linguagem gramaticalmente articulada seja transmissível e apreensível entre dois interactantes; (ii) a pretensão de verdade (Wahrheit) de um determinado conteúdo proposicional em relação ao mundo objetivo; (iii) a pretensão de adequação normativa (Richtigkeit) da sentença com relação ao mundo social; e (iv) a pretensão de sinceridade (Wahrhaftigkeit), que exige que a sentença expresse, fidedignamente e sem distorções, a intenção do falante no mundo subjetivo (Habermas, 1980b:110; 1976:354-355; 1981,v. 1:142 ss.). A tradição sociológica da teoria da ação dispõe de três paradigmas para cada uma das relações entre o sujeito e o mundo: o modelo teleológico para o mundo objetivo (Weber), o modelo normativo para o mundo social (Durkheim/ Parsons) e o modelo expressivo-dramatúrgico para o mundo subjetivo (Goffman). Na reconstrução habermasiana da tradição sociológica, esses três modelos seriam concebidos monologicamente e apenas a teoria do discurso permitiria a reflexividade dialógica:

Apenas o modelo do agir comunicativo pressupõe a linguagem como um meio para o entendimento integral, por intermédio do qual falante e ouvinte, partindo do horizonte pré-interpretado e pré-compreendido de seu mundo da vida, reportam-se a algo no mundo objetivo, social e

DADOS - Revista de Ciências Sociais, Rio de Janeiro, vol. 60, n’ 2, 2017 
João Paulo Bachur

subjetivo a fim de negociar a definição da situação vivenciada de maneira comum por ambos (Habermas, 1981, v. 1:142).

Nesse passo, Habermas se apropria da teoria do símbolo de Bühler para distinguir formas do uso da linguagem. Bühler é talvez o mais renomado linguista alemão, responsável pela formulação de um modelo triádico para as funções simbólicas até hoje muito influente na linguística e na teoria da linguagem. Segundo Bühler, o símbolo tem três funções elementares: a função representativa (Darstellung), por meio da qual algo do mundo é simbolizado; a função expressiva (Ausdruck), por intermédio da qual algo é exteriorizado; e a função de apelo (Appell), por meio da qual a atenção do outro é dirigida (Bühler, 1999). Habermas se apropria dessa tríade para classificar formas de uso linguístico. Os participantes em um discurso podem não apenas reportar algo existente no mundo, eles podem também usar a linguagem de maneira regulativa ou expressiva: participantes em um discurso usam a linguagem para $(i)$ chegar a um consenso quanto a um estado de coisas no mundo, (ii) estabelecer uma relação interpessoal e (iii) expressar reciprocamente intenções ou vivências pessoais. A partir daí, Habermas reinterpreta o ato de fala como a oferta de uma relação interpessoal e situa, na aceitação de tal oferta, o sucesso performativo do ato de fala. $\mathrm{O}$ mundo da vida, entendido como "reservatório de obviedades e convencimentos inabaláveis", funciona como horizonte para o entendimento linguístico: "todo ato de entendimento linguístico pode ser compreendido como um procedimento cooperativo de interpretação, voltado à definição da situação intersubjetivamente vivenciada" (Habermas, 1981, v. 2:189; 1981, v. 1:107).

Assim se revela a dupla estrutura específica da linguagem: a reflexividade da linguagem permite diferenciar o elemento proposicional de uma sentença da sentença concretamente pronunciada por um interactante, de forma que uma invariância relativa possa ser isolada e identificada. Toda sentença dispõe de uma informação (no âmbito do conteúdo proposicional) e de um sentido prático (Verwendungssinn) válido para o emprego concreto dessa informação (Habermas, 1976:405-407). Por essa razão a postura, a atitude (Einstellung) do falante cria uma relação interpessoal: um ato de fala é bem-sucedido quando o ouvinte não apenas compreende a sentença pronunciada, mas quando a relação interpessoal proposta pelo falante é acatada (Habermas, 1981, v. 1:394-398; 1976:428). A força performativa do ato de fala está em motivar o ouvinte a acatar, sem ressalvas, a relação interpessoal proposta pelo falante. 
A fim de que esse circuito seja estabelecido, é preciso que uma linearidade entre "intenção - sentença linguística - significado" seja estabelecida sem ruídos. Na versão de Habermas para a teoria dos atos de fala, o sucesso é medido pelo engajamento pessoal na busca pelo consenso, que deve ser alcançado de maneira autorreferencial, i.e., o engajamento não pode ser imposto institucionalmente, $a b$ extra, mas tem de ser buscado espontaneamente pelos participantes em um discurso. Por essa razão, Habermas insiste em qualificar o discurso como composto por atos de fala "desvinculados institucionalmente" ${ }^{5}$. Do contrário, seria impossível motivar o engajamento pessoal comunicativamente e obter o consenso apenas com base na força do melhor argumento (Habermas, 1976:402-403 e 432-435).

Para tanto, duas condições têm de ser satisfeitas. Em primeiro lugar, o consenso é apresentado como modo original e telos da comunicação humana (Habermas, 1981, v. 1:387-388; 1992:18). Em segundo lugar, e mais importante, não vale mentir: "É preciso assegurar que o falante não pretenda dizer nada além daquilo que ele literalmente diz" (Habermas, 1981, v. 1:400). Habermas se apropria do "princípio da expressividade" (principle of expressivity) de John Searle, mas radicaliza-o ao paroxismo. Enquanto Searle define o princípio da expressividade como a possibilidade de que aquilo que o falante queira exprimir possa de fato sê-lo sem distorções (whatever can be meant can be said), Habermas transforma tal princípio em uma regra de sinceridade absoluta, pela qual aquilo que é dito é dito sempre de maneira sincera (tipo: I really mean what I am saying!). Habermas tem de atrelar intenção, sentença e significado do ato de fala, a fim de que a literalidade do significado remanesça uma função interna da comunicação (Greve, 2002:377-378).

O problema é que essa identificação desnatura o fenômeno discursivo. Esse último somente tem lugar quando intenção, significado e recepção da mensagem comunicativa podem ser desacoplados um do outro, abrindo brechas para mal-entendidos ou zonas de penumbra que mantêm a comunicação pulsante. Não sem razão, o grande feito de Austin foi demonstrar o desacoplamento entre o elemento proposicional da comunicação, a informação, e a ilocução, o sentido prático da sentença em seu uso concreto (Austin, 1962). Mais ainda, diante de uma plêiade de cursos de ação viáveis, é impossível aferir a sinceridade dos agentes envolvidos - a não ser que ele se comprometa de antemão a agir sinceramente. Só assim seria possível assegurar a linearidade entre inten-

DADOS - Revista de Ciências Sociais, Rio de Janeiro, vol. 60, nº 2, 2017 
ção, sentença e significado. Mas aí, mais uma vez, o núcleo duro do discurso é preenchido pela operação monológica de um sujeito, pois somente ele pode saber, em seu íntimo, se o que foi dito o foi sinceramente. Nessa medida, o ato de fala na releitura habermasiana basta a si mesmo, pois "o falante sempre pronuncia uma sentença com o propósito comunicativo de ser entendido e de que sua oferta comunicativa seja aceita" (Habermas 1981, v. 1: 389; ênfases no original). Ora, a regra da sinceridade e o consenso como telos da comunicação humana asseguram, portanto, que o entendimento linguístico seja alcançado - à custa de uma clara tautologia: como todos os interactantes não dizem nada além daquilo que literalmente dizem, como todo interactante tenta estabelecer uma relação pessoal de forma a alcançar o consenso, e como a comunicação humana é naturalmente voltada ao consenso, tem-se então o verdadeiro consenso.

\section{O COMPROMETIMENTO ÍNTIMO COM A BUSCA PELO CONSENSO}

Recapitulando: como vimos nas seções anteriores, uma argumentação racional tem de contar, de saída, com a pressuposição da situação ideal de fala, mas não conta com um critério externo para distinguir o verdadeiro consenso do falso, como admite o próprio Habermas: "falta um critério de julgamento externo, de forma que nunca poderemos ter certeza de se, em uma determinada situação, conduzimos um discurso ou se ao contrário estamos enredados em um discurso aparente, agindo de acordo com pressões externas", pois um consenso racional somente pode ser realmente distinguido "em última instância, pela tomada de posição com relação à situação ideal de fala" (Habermas, 1972:179-180; ênfases no original), em que só vale a força do melhor argumento ${ }^{6}$. Para assegurar essa tomada de posição, Habermas relê a teoria dos atos de fala de Austin, de forma que o sucesso performativo da linguagem passa a residir na capacidade de estabelecer uma relação interpessoal fundada na sinceridade e na literalidade do que é dito. A única peça faltante é a seguinte: os interactantes precisam querer alcançar o consenso.

Nesse ponto, Habermas faz o derradeiro movimento em direção a uma fundamentação solipsista do discurso: ao admitir que o discurso depende da escolha dos interactantes, pois agir comunicativo e agir estratégico estão simultaneamente disponíveis para ele, fica claro que o fundamento do discurso é, na verdade, o autocomprometimento moral, íntimo, do sujeito. Com isso, a motivação do discurso está definitiva- 
mente enraizada em uma opção subjetiva a cargo do ator individual, pois nada há que permita estabilizar socialmente uma opção coletiva pelo discurso racional - o sujeito habermasiano tem de querer alcançar o consenso:

Na medida em que defino o agir estratégico e o agir comunicativo como tipos, parto do pressuposto de que as ações concretas se permitem classificar sob esses pontos de vista. Com "agir estratégico" e "agir comunicativo" não designo apenas dois aspectos analíticos, a partir dos quais uma mesma ação poderia ser descrita, de um lado, como a influência recíproca de atores orientados por fins racionais e, de outro, como processo de entendimento entre interactantes que compartilham o mundo da vida. Ao contrário, é possível diferenciar tais ações sociais de acordo com a tomada de uma atitude orientada ao êxito estratégico ou ao entendimento linguístico por parte dos participantes (Habermas, 1981, v. 1:385-386; ênfases no original, sublinhados meus).

Essa passagem é absolutamente central para o argumento deste artigo. Nota-se que Habermas define o agir estratégico e o agir comunicativo como crivos analíticos por meio dos quais uma mesma ação pode ser descrita, a depender da atitude tomada pelo participante no discurso. É então a postura individual que define se, no caso concreto, trata-se de agir estratégico ou agir comunicativo. Mais uma vez, o critério para diferenciá-las não é comunicativo, mas está enraizado na subjetividade. Por isso, resta aos atores uma espécie de dever moral para com a busca pelo consenso:

os atores têm de passar da posição objetivista de um ator racional orientado ao êxito estratégico, que procura provocar um determinado efeito no mundo, para a posição performativa de um falante que deseja se entender com uma segunda pessoa a respeito de algo no mundo (Habermas, 1988:72).

Por que eles têm de passar da postura estratégica para a postura comunicativa? Não há nenhum elemento teórico que justifique a precedência do agir comunicativo em desfavor do agir estratégico. Não obstante, é exatamente isso que Habermas impõe aos agentes: eles têm de suspender o ímpeto estratégico antes de tomar parte no discurso. Com isso, opera-se não apenas uma petição de princípio, pois o entendimento linguístico deixa de ser resultado do discurso e passa a ser uma de suas premissas; o discurso depende estritamente do sujeito racional e da suspensão monológica de seu ímpeto de agir estrategicamente:

DADOS - Revista de Ciências Sociais, Rio de Janeiro, vol. 60, nº 2, 2017 
João Paulo Bachur

As energias vinculantes da linguagem somente podem ser mobilizadas para a coordenação de planos de ação quando os participantes de um discurso suspendem a perspectiva objetivante de um observador, de um ator orientado imediatamente ao próprio sucesso individual, em favor da atitude performativa de um falante que quer se entender com uma outra pessoa sobre algo no mundo (Habermas, 1992:34; ênfases no original, sublinhados meus).

As passagens citadas põem a nu a absoluta necessidade de um comprometimento íntimo prévio em favor do discurso. E o problema está justamente no fato de que o insucesso da postura performativa conduz à recaída imediata no agir estratégico: "Tão logo tais expectativas de racionalidade se revelem falseadas, os participantes no discurso mudam sua perspectiva, abandonando a postura performativa em favor de uma postura objetivante" (Habermas, 1992:36). O interactante habermasiano tem de ser então um "protestante dialógico", por assim dizer: tem de se manter firme em sua fé no consenso, pois não há instância social que o auxilie nessa tarefa. Com efeito, a insistência de Habermas no caráter anti-institucional da situação ideal de fala, com todas as consequências daí advindas, elimina a possibilidade de estabilizar a postura performativa socialmente, i.e., por uma instância da sociedade, pois isso inevitavelmente implicaria alguma forma de institucionalização. Como isso não está em questão, Habermas tem forçosamente de recorrer ao sujeito. Ou seja, é preciso que o sujeito suspenda, por sua própria iniciativa, o impulso em prol do agir estratégico, substituindo-o pela ação orientada à busca do entendimento linguístico. O sujeito precisa decidir, sozinho, adotar a postura performativa em favor da busca pelo entendimento linguístico. Mas, nessa medida, a teoria do agir comunicativo tem de redundar cabalmente em uma teoria da subjetividade monológica:

A ideia central é a da autonomia da subjetividade. Foi o grande mérito de Descartes reconhecer a subjetividade como fundamento de toda e qualquer pretensão de validade. O sujeito não pode admitir nada como verdadeiro, justo ou belo, que ele mesmo não compreenda como tal por força do autoconvencimento livre e alheio a pressões externas. [...] Os sujeitos, e não a comunicação, são a pedra angular de toda pretensão de validade (Grondin, 1987:34).

Não por outra razão, "a distinção entre a ação voltada ao consenso e a ação orientada ao sucesso parece estar (ainda) baseada na intenção do falante" (Skjei, 1985:92). Quando os dois cursos de ação, o agir estraté- 
gico e o agir comunicativo, estão simultaneamente disponíveis para o sujeito, ele tem de suspender o ímpeto individualista e adotar a postura voltada à busca pelo consenso - mas para tanto, o sujeito conta apenas com o autocomprometimento moral e prévio de sua vontade. Ao sustentar que os participantes no discurso precisam suspender sua orientação ao êxito individual, liberando a energia integradora da linguagem, Habermas tem de assegurar que essa suspensão ocorra de alguma maneira. Tal suspensão somente pode ocorrer em obediência a uma regra de dever moral. O sujeito tem de estar convencido da necessidade de suspender seu ímpeto de agir estrategicamente - do contrário, não há engajamento possível no discurso que visa o consenso. Mas esse autoconvencimento é sempre interno ao sujeito, vez que ele não pode ser comunicativamente testado. É, portanto, no solipsismo da subjetividade que reside o fundamento do discurso.

Em síntese: a necessidade de distinguir o verdadeiro e o falso consenso exigiu a pressuposição de uma situação ideal de fala, que, por sua vez, conduziu a uma releitura da teoria da linguagem de forma a assegurar a sinceridade absoluta dos interactantes e, por fim, também a adesão prévia à busca pelo entendimento linguístico. Esse, o miolo anti-institucional que liga esfera pública e deliberação democrática, preenchendo as extremidades institucionais da teoria social habermasiana. As consequências para a democracia são consideráveis.

\section{SIMETRIA DISCURSIVA E DELIBERAÇÃO DEMOCRÁTICA}

O problema teórico da impossibilidade de distinguir o verdadeiro e o falso consenso reaparece, na teoria da democracia deliberativa, como o problema prático de saber se uma determinada deliberação oficial, uma lei aprovada consoante os ritos parlamentares típicos, representa o resultado de uma deliberação racional e dialógica ou se, ao contrário, é mera resultante das pressões de diversos grupos de interesse agindo estrategicamente. Como vimos até agora, a teoria do agir comunicativo não dispõe de um recurso teórico para aferir o verdadeiro consenso e, tampouco, a origem dialógica de uma decisão oficial, que não o prévio comprometimento moral dos envolvidos. E isso, como reiteradamente argumentado até aqui, somente pode ser fruto da razão subjetiva e monológica.

É claro que Habermas sustenta o caráter constitutivamente dialógico de sua ética do discurso: a adoção da postura performativa em prol da

DADOS - Revista de Ciências Sociais, Rio de Janeiro, vol. 60, nº 2, 2017 
busca do entendimento linguístico está pautada por um "princípio de universalização" equivalente a uma troca de papéis universal (role taking, no sentido de Mead): "Na ética do discurso, os procedimentos da argumentação moral tomam o lugar do imperativo categórico" (Habermas, 2009, 3:119; também Habermas, 1983:76). Mas a mencionada "troca universal de papéis sociais" é realizada de maneira verdadeiramente argumentativa? Uma vez que a pretensão de validade da sinceridade está centrada em um componente não linguístico - pois sinceridade somente pode ser testada pelo comportamento consistente com o enunciado linguístico, como reconhece o próprio Habermas (1983:69) - então tal "troca universal de papéis sociais" tem de ocorrer, necessariamente, como processo mental de um sujeito: eu tomo a perspectiva do outro para testar se uma lei é moralmente aceitável. A regra da sinceridade inviabiliza que essa troca de papéis seja realizada de maneira efetivamente dialógica, pois não é possível testar, discursivamente, se o outro quer realmente dizer aquilo que de fato diz. A sinceridade das posições sustentadas no debate somente é acessível monologicamente: somente eu mesmo tenho acesso à sinceridade de minhas posições argumentativas. A tentativa de externar minha sinceridade é sempre paradoxal.

Por isso, Habermas leva para seu modelo de democracia deliberativa o elemento ficcional da situação ideal de fala. O discurso racional assume como premissas: (i) a impossibilidade de uma interrupção arbitrária da argumentação; (ii) liberdade e autonomia na seleção de temas a serem problematizados, bem como o uso da melhor informação disponível e a participação simétrica na argumentação; e (iii) exclusão de todo e qualquer tipo de coerção que não a força do melhor argumento (Habermas, 1992:282). Que tais premissas são irreais, não há dúvida: o debate parlamentar é muito mais um procedimento burocrático e documental entremeado de regras de competência para proposituras de projetos de lei, cheio de prazos e ritos para apresentação de emendas, convocação de sessões obrigatórias de discussão com limitação temporal, regras de quórum mínimo para votações nominais etc., do que um diálogo racional em sentido habermasiano ${ }^{7}$. No entanto, não se trata aqui de opor uma descrição realista da democracia a um modelo ideal, algo do tipo "Dahl versus Habermas". Aliás, o caráter idealista da democracia deliberativa não é, em si mesmo, um problema. Modelos ideais são extremamente poderosos quando apoderados por forças sociais e mobilizados para a transformação do estado de coisas vigente. E, certamente, o paradigma da democracia deliberativa poderia even- 
tualmente inspirar reformas institucionais que ampliassem arenas de debate e discussão, revitalizando a formação da vontade coletiva e a representação política ${ }^{8}$. O aspecto verdadeiramente problemático do modelo habermasiano para a democracia deliberativa parece ser outro, qual seja, a projeção da simetria discursiva derivada da situação ideal de fala para a "base material" da sociedade, por assim dizer. Conceitualmente, a situação ideal de fala implica a simetria radical entre os participantes do discurso. No entanto, derivar daí um pressuposto empírico para a democracia coloca o modelo deliberativo em xeque.

Com efeito, toda a teoria habermasiana dá de barato o equacionamento dos problemas distributivos intrínsecos à sociedade capitalista. $\mathrm{Na}$ Teoria do agir comunicativo, Habermas separa muito nitidamente a reprodução material da sociedade, deixada a cargo dos sistemas da economia e do aparato estatal, em que vige plenamente o agir estratégico, da reprodução simbólica do mundo da vida, espaço passível para o entendimento linguístico. E é no desacoplamento entre sistemas e mundo da vida, na possibilidade de colonização interna desse último pelos primeiros, que reside o grande risco (Habermas, 1981, v. 2; 1985). Os conflitos internos à economia (e ao aparato estatal) são relativamente minimizados quando a atenção se volta aos conflitos entre sistemas e mundo da vida ou aos conflitos adstritos à esfera simbólica e cultural: “Em suma, os novos conflitos sociais são desencadeados não mais por problemas distributivos, mas por questões relativas à gramática das formas de vida" (Habermas, 1981, v. 2:576; ênfases no original). O diagnóstico parece ter levado os trinta anos gloriosos da socialdemocracia europeia muito ao pé da letra (face aos 150 anos de lutas de classes que a precederam).

De certa maneira, um dos problemas mais difíceis encontrados pelas democracias contemporâneas está relacionado à necessidade de equacionar uma agenda de inclusão social herdada do século XX com o arcabouço institucional moldado pelo século XIX (Przeworski, 1985; Przeworski e Sprague, 1986; Castel, 1999). Com efeito, mesmo após a crise da social-democracia e sua suplantação pelo neoliberalismo, a pauta herdada da questão social sobrevive, ainda que em outro contexto - trata-se sempre de ampliar ou restringir direitos sociais, ou ainda da disputa entre políticas de austeridade fiscal e monetária e políticas sociais, uma característica de quase todo governo democrático atual. Nesse contexto, a situação ideal de fala serve não como ideal para o redesenho de aspectos institucionais de forma a dar expressão a esse ten- 
sionamento. Muito pelo contrário, Habermas pressupõe o pleno equacionamento da questão distributiva como precondição para o agir comunicativo:

O potencial de um pluralismo cultural emancipado somente poderá se desenvolver plenamente apoiado sobre uma base [societal] que tenha se destacado das constrições de classe e se desvencilhado dos grilhões centenários da exploração e da estratificação social - um potencial que, certamente, é tão repleto de conflitos quanto de formas de vida capazes de engendrar novos significados (Habermas, 1992:374).

Com isso, Habermas pretendia sustentar que a superação dos conflitos de classe não implicaria a eliminação dos conflitos sociais, o que é correto. Mas há, nesse passo, uma clara inversão de planos. A simetria discursiva, construída no plano conceitual como crivo crítico que permite recortar um tema do mundo da vida e torná-lo objeto da argumentação racional, é sub-repticiamente transferida para o plano empírico relativo ao equacionamento fático das chances de vida. Essa transição do plano conceitual para o plano empírico compromete justamente o aspecto potencialmente mais crítico das instituições democráticas: a capacidade de tematizar assimetrias interpessoais.

A história da democracia é marcada não apenas pela expansão do sufrágio universal e pela institucionalização da concorrência partidária eleitoral; do ponto de vista material, ela inclui definitivamente a luta por direitos sociais (Marshall, 1950/1992). Ao pressupor que tais conflitos já estão de alguma maneira equacionados e que o grande potencial da democracia deliberativa está em trabalhar questões relativas à reprodução simbólica e cultural do mundo da vida (que é evidentemente muito conflituosa; em momento algum nega-se isso), Habermas abre mão do potencial crítico da forma democrática - a possibilidade de tematizar assimetrias entre pessoas e grupos. A simetria discursiva, pressuposta na situação ideal de fala, quando projetada empiricamente como pano de fundo para o agir comunicativo, acaba por comprometer o alcance do paradigma deliberativo proposto por Habermas.

\section{CONCLUSÃO}

Este artigo procurou demonstrar como a intersubjetividade pretendida pela teoria do discurso de Habermas é, ao final, solapada por premissas de caráter monológico, pois a emergência do discurso pressupõe, em última instância, o solipsismo do sujeito racional. A teoria do 
agir comunicativo é, antes de tudo, uma teoria da subjetividade - ela é a pedra angular da intersubjetividade pretendida por Habermas.

O artigo adotou a reflexividade da linguagem como fio condutor, pois essa categoria permite não apenas compreender a distinção-chave da teoria social habermasiana, qual seja, a diferença entre agir comunicativo e discurso, mas também assegura uma leitura homogênea que nos permite transitar do estudo histórico da esfera pública até o modelo procedimental do direito e da democracia sem grandes deslocamentos conceituais. Com efeito, trata-se de uma constante na reflexão habermasiana: a linguagem tem de romper com sua rotina cotidiana e se autoexcepcionalizar, a fim de agir sobre o mundo. Isso vale para a esfera pública burguesa do século XVIII, para a transição entre as interações corriqueiras e a argumentação racional, bem como para o modelo procedimental de democracia deliberativa.

Essa premissa da reflexividade da linguagem exige que a intersubjetividade não tenha outro fundamento além dela mesma. Na busca por esse fundamento, no entanto, Habermas finda por se socorrer da figura que ele mais combateu ao longo de seu percurso teórico, qual seja, a razão monológica do sujeito solipsista. Com efeito, se a intersubjetividade deve surgir de maneira autônoma, não há outro crivo de validade para o discurso que não o próprio discurso. Mas os participantes de um discurso nunca sabem, na verdade, se estão em busca do verdadeiro consenso ou se estão vivendo apenas um simulacro de consenso. A solução de Habermas é a pressuposição da situação ideal de fala, uma "ficção operacionalmente efetiva no processo comunicativo" que elimina as distorções comunicativas e faz com que os interactantes busquem o consenso com base apenas na força do melhor argumento.

Para tanto, foi necessário reconstruir a teoria dos atos de fala, localizando no estabelecimento de uma relação interpessoal o sucesso comunicativo. É vedado aos falantes a mentira, a insinuação e qualquer outra sentença linguística que não expresse, literalmente, sua intenção subjetiva autêntica, evitando assim distorções de sentido. Dado então que os interactantes estão sempre envolvidos em um discurso com a intenção de alcançar o consenso e que não há distorções linguísticas, o entendimento linguístico pode ser alcançado. Na verdade, ele está inscrito nas premissas da reconstrução habermasiana da teoria da linguagem. Falta aos participantes apenas a vontade individual para buscar o entendimento linguístico. Por isso, diante da alternativa entre o agir estratégico e o agir comunicativo, ambos simultaneamente disponí-

DADOS - Revista de Ciências Sociais, Rio de Janeiro, vol. 60, nº 2, 2017 
veis para os interactantes, eles têm de suspender o impulso de agir estrategicamente em prol da busca pelo consenso, o que somente pode ser realizado por um sujeito solipsista, prévia e moralmente comprometido com a busca pelo consenso. Ao fim e ao cabo, o consenso não é resultado, mas premissa do discurso. Os interactantes partem, antes do discurso, de uma situação em que já estão moralmente engajados e intimamente comprometidos com o entendimento linguístico. Mas então o fundamento do discurso é o solipsismo do sujeito.

As consequências para o modelo deliberativo da democracia não são triviais. De um lado, a democracia deixa de poder tematizar justamente aquilo que foi sua pauta central ao longo do século XX: as discrepâncias fáticas entre eleitores, ou, em outras palavras, a desigualdade social. Ao pressupor que as questões distributivas tenham sido de alguma maneira solucionadas para que o agir comunicativo e a democracia deliberativa tenham lugar, vale indagar: o que restaria então à democracia para deliberar? Com isso, a democracia perde a força crítica que lhe é característica. O esvaziamento da questão distributiva é fatal para o modelo procedimental da democracia deliberativa. Aliás, as recentes crises financeiras da primeira década do século XXI parecem apontar para uma conjuntura econômica bastante diferente do welfare state de pleno emprego vigente quando Habermas se enveredou na busca por uma teoria da linguagem que assegurasse o entendimento linguístico. Afinal de contas, não está dado que a democracia funcionará, para todo o sempre e de maneira absolutamente teleológica e determinista, como aquela pretensa "superestrutura que instrumentaliza a dominação de classe", como chega a afirmar o marxismo mais remoto. A democracia pode funcionar como contraponto aos processos de acumulação e força motriz para procedimentos de inclusão social, mas sua concepção pelo viés da simetria discursiva esteriliza justamente seu aspecto crítico central: a possibilidade de tematizar assimetrias. Essa contingência é o que assegura à democracia, a despeito das mazelas de seu funcionamento rotineiro, alguma reserva crítica; é aí que remanesce algum espaço, ainda que diminuto, para que uma deliberação acerca das assimetrias sociais venha a ser imposta pela periferia da sociedade.

(Recebido para publicação em dezembro de 2015) (Aprovado para publicação em fevereiro de 2017) 
Intersubjetividade ou Solipsismo?

\section{NOTAS}

1. Observe-se que o componente normativo não é indispensável à teoria crítica - muito pelo contrário, ele parece justamente encurtar o alcance da crítica (Bachur, 2014). Não obstante, a versão preponderante da teoria crítica de Frankfurt se assume hoje claramente normativa (Voirol, 2012).

2. Aqui cabe uma observação acerca do papel da escrita na compreensão da esfera pública. Enquanto Koselleck atribui um papel absolutamente central à forma escrita (Koselleck, 1959:87 e ss.), Habermas prioriza essencialmente a comunicação oral: as tecnologias da comunicação escrita, essencialmente desenvolvidas em função da expansão do comércio, não são suficientes para formar a esfera pública porque remanescem uma forma privada de intercâmbio (Habermas, 1962:72). Não obstante o texto impresso tenha sido fundamental para o desenvolvimento institucional da esfera pública, são as conversas nos cafés e salões europeus dos séculos XVIII e XIX que constituem seu núcleo autêntico, pois aquilo que se leu adquire de fato sentido quando se discute a respeito (Habermas, 1962:15). Essa visão, no entanto, além de negligenciar a autonomia da escrita, apenas reproduz os estudos mais remotos sobre a opinião pública (Tarde, 1901).

3. Quanto à necessidade de institucionalização do discurso, veja-se igualmente Habermas (1983:102; 1985:417-418)

4. Um exemplo ajuda a entender a diferença entre discurso e agir comunicativo e o trânsito de um ao outro: palavras como "ricos" e "pobres" são empregadas cotidianamente sem que seja necessário defini-las a cada momento; a discussão parlamentar de um programa de transferência de renda em favor dos pobres e financiado por meio da tributação dos ricos exigirá, ao contrário, uma definição legislativa dessas categorias. A questão habermasiana está em definir tais categorias por meio de uma ar gumentação racional conduzida em bases universais e fundada na busca dialógica do entendimento linguístico (e não, por exemplo, na barganha corporativa entre grupos de interesse).

5. É fato que o mundo da vida é repleto de relações de poder, dificultando a hipótese empírica de atos de fala institucionalmente desenraizados (Allen, 2012).

6. Essa visão radical do consenso é amenizada na fase final da produção habermasiana, em que se distinguem consenso forte e consenso fraco e, com isso, dois tipos de agir comunicativo: “Consenso [Einverständnis] em sentido estrito é obtido quando os participantes no discurso podem aceitar, com base nos mesmos motivos, uma determinada pretensão de validade, enquanto entendimento [Verständigung] tem lugar quando um dos interactantes percebe que o outro, à luz de suas preferências individuais e em determinadas circunstâncias, tem bons motivos para a posição por ele sustentada, i.e., motivos que, para ele, são suficientes, sem que o primeiro interactante, à luz de suas próprias preferências, tenha que se apropriar e se convencer de tais motivos" (Habermas, 1999:116-117; ênfases no original). Nesse sentido, o agir comunicativo pode se basear em argumentos e motivos independentes dos interactantes ou centrado nos interactantes, dependendo dos fins por eles perseguidos. Nessa medida, é possível passar do consenso fraco ao consenso forte, "quando o que o entendimento é estendido para abranger motivos normativos voltados à escolha dos fins a serem perseguidos" (idem:122). Essa transigência com a busca de fins individuais dificulta

DADOS - Revista de Ciências Sociais, Rio de Janeiro, vol. 60, nº 2, 2017 


\section{João Paulo Bachur}

ainda mais a fundamentação exclusivamente comunicativa do discurso (Greve, 1999).

7. Talvez a melhor descrição da realidade - um tanto frustrante - do procedimento parlamentar possa ser obtida pelas lentes frias de Luhmann (1969).

8. Correndo-se sempre o risco, claro, de que o élan participativo venha a ser convertido na multiplicação de conselhos (deliberativos ou consultivos) atrelados a órgãos oficiais e eventualmente instrumentalizados pelo governo ou pela oposição (cf. Miller, 1998). 


\section{REFERÊNCIAS BIBLIOGRÁFICAS}

ALLEN, Amy. (2012), “The Unforced Force of the Better Argument: Reason and Power in Habermas' Political Theory". Constellations, vol. 19, no 3, pp. 353-368.

AUSTIN, John L. (1962), How To Do Things With Words. (2a ed.). Oxford, Oxford University Press.

AVRITZER, Leonardo. (1999), “Teoria Crítica e Teoria Democrática: Do Diagnóstico da Impossibilidade da Democracia ao Conceito de Esfera Pública". Novos Estudos CEBRAP, vol. 53, pp. 167-188.

BACHUR, João Paulo. (2014), “Niklas Luhmann and His Legacy” (resenha de Marc Amstutz e Andreas Fischer-Lescano, Kritische Systemtheorie: Zur Evolution einer normativen Theorie. Bielefeld: Transcript, 2013). International Sociology Reviews, vol. 29, no 5, pp. 405-408.

BERGER, Peter L.; LUCKMANN, Thomas. (1966), The Social Construction of Reality: A Treatise in the Sociology of Knowledge. New York, Anchor Books.

BÜHLER, Karl. (1999), Sprachtheorie: Die Darstellungsfunktion der Sprache. (3ª ed.). Stuttgart, UTB.

CASTEL, Robert. (1999), Les Métamorphoses de la Question Sociale. Paris, Folio.

GARNHAM, Nicholas. (1992), "The Media and the Public Sphere", in C. Calhoun (ed.), Habermas and the Public Sphere. Cambridge/London, MIT Press, pp. 359-376.

GREVE, Jens. (1999), “Sprache, Kommunikation und Strategie in der Theorie von Jürgen Habermas". Kölner Zeitschrift für Soziologie und Sozialpsychologie, vol. 51, pp. 232-259.

. (2002), “Bedeutung, Handlung und Interpretation: Zu den Grundlagen der verstehenden Soziologie". Zeitschrift für Soziologie, vol. 31, no 5, pp. 373-390.

GRONDIN, Jean. (1987), "Hat Habermas die Subjektphilosophie verabschiedet?". Allgemeine Zeitschrift für Philosophie vol. 12, no 1, pp. 25-37.

HABERMAS, Jürgen. (1962), Strukturwandel der Öffentlichkeit: Untersuchungen zu einer Kategorie der bürgerlichen Gesellschaft. Frankfurt am Main, Suhrkamp.

(1971), “Vorbereitende Bemerkungen zu einer Theorie der kommunikativen Kompetenz", in J. Habermas; N. Luhmann, Theorie der Gesellschaft oder Sozialtechnologie? - Was leistet die Systemforschung?. Frankfurt am Main, Suhrkamp, pp. 101-141.

(1972), "Wahrheitstheorien", in J. Habermas, Vorstudien und Ergänzungen zur Theorie des kommunikativen Handelns. (3a ed.). Frankfurt am Main, Suhrkamp, pp. 127-183.

. (1973), Legitimationsprobleme im Spätkapitalismus. Frankfurt am Main, Suhrkamp.

(1976), "Was heißt Universalpragmatik?", in J. Habermas, Vorstudien und Ergänzungen zur Theorie des kommunikativen Handelns. (3a ed.). Frankfurt am Main, Suhrkamp, pp. 353-440.

(1980a), "Replik auf Einwände", in Vorstudien und Ergänzungen zur Theorie des kommunikativen Handelns. ( $3^{a}$ ed.). Frankfurt am Main, Suhrkamp, pp. 475-570.

DADOS - Revista de Ciências Sociais, Rio de Janeiro, vol. 60, n² 2, 2017 


\section{João Paulo Bachur}

. (1980b), "Vorlesungen zu einer sprachtheoretischen Grundlegung der Soziologie", in Vorstudien und Ergänzungen zur Theorie des kommunikativen Handelns (3a ed.) Frankfurt am Main, Suhrkamp, pp. 11-126.

(1981), Theorie des kommunikativen Handelns (4a ed.). Frankfurt am Main, Suhrkamp.

. (1982), "Erläuterungen zum Begriff des kommunikativen Handelns", in Vorstudien und Ergänzungen zur Theorie des kommunikativen Handelns. (3a ed.). Frankfurt am Main, Suhrkamp, pp. 571-606.

(1983), Moralbewußtsein und kommunikatives Handeln. Frankfurt am Main, Suhrkamp.

(1984), Vorstudien und Ergänzungen zur Theorie des kommunikativen Handelns. (3a ed.). Frankfurt am Main, Suhrkamp.

. (1985), Der philosophische Diskurs der Moderne. Frankfurt am Main, Suhrkamp.

. (1988), Nachmetaphysisches Denken: Philosophische Aufsätze. Frankfurt am Main, Suhrkamp.

. (1992), Faktizität und Geltung: Beiträge zur Diskurstheorie des Rechts und des demokratischen Rechtsstaats. (4a ed.). Frankfurt am Main, Suhrkamp.

. (1996), Die Einbeziehung des Anderen: Studien zur politischen Theorie. Frankfurt am Main, Suhrkamp.

(1999), Wahrheit und Rechtfertigung: Philosophische Aufsätze. Frankfurt am Main, Suhrkamp.

(2009), Diskursethik. Philosophische Texte, v. 3. Frankfurt am Main, Suhrkamp.

HORKHEIMER, Max; ADORNO, Theodor W. (1947), Dialektik der Aufklärung: Philosophische Fragmente. Frankfurt am Main, Fischer.

KOSELLECK, Reinhart. (1959), Kritik und Krise: Eine Studie zur Pathogenese der bürgerlichen Welt. (8a ed.). Frankfurt am Main, Suhrkamp.

KRÄMER, Sybille. (2001), Sprache, Sprechakt, Kommunikation: Sprachtheoretische Positionen des 20. Jahrhunderts. Frankfurt am Main, Suhrkamp.

LUCKMANN, Thomas; SCHÜTZ, Alfred. (1975), Strukturen der Lebenswelt. Konstanz, UVK.

LUHMANN, Niklas. (1969), Legitimation durch Verfahren. Frankfurt am Main, Suhrkamp.

(1971), "Systemtheoretische Argumentationen: Eine Entgegnung auf Jürgen Habermas", in J. Habermas; N. Luhmann, Theorie der Gesellschaft oder Sozialtechnologie? - Was leistet die Systemforschung?. Frankfurt am Main, Suhrkamp, pp. 291-405.

(1980), "Interaktion in Oberschichten: Zur Transformation ihrer Semantik im 17. und 18. Jahrhundert", in Gesellschaftsstruktur und Semantik: Studien zur Wissenssoziologie der modernen Gesellschaft. Frankfurt am Main, Suhrkamp, pp. 72-161, vol. 1.

. (1995), "Quod Omnes Tangit: Remarks on Jürgen Habermas's Legal Theory". Cardozo Law Review, vol. 17, pp. 883-899. 
MARKELL, Patchen. (1997), "Contesting Consensus: Rereading Habermas on the Public Sphere". Constellations, vol. 3, no 3, pp. 377-400.

MARSHALL, Thomas H. (1950), "Citizenship and Social Class", in T. H. Marshall; T. Bottomore, Citizenship and Social Class. London, Pluto Press, pp. 3-51, Parte I.

MILLER, Max. (1998), “Bürgerarenen und demokratischer Prozeß”, in H. J. Giegel (ed.), Konflikt in modernen Gesellschaften. Frankfurt, Suhrkamp, pp. 288-326.

NEVES, Marcelo. (2006), Entre Têmis e Leviatã: Uma Relação Difícil. São Paulo, Martins Fontes.

NOBRE, Marcos; REPA, Luiz (eds.). (2012), Habermas e a Reconstrução: Sobre a Categoria Central da Teoria Crítica Habermasiana. Campinas, Papirus.

NOBRE, Marcos; TERRA, Ricardo; SEGATTO, Antonio Ianni (eds.). (2008), Direito e Democracia: Um Guia de Leitura de Habermas. São Paulo, Malheiros.

PRZEWORSKI, Adam. (1985), Capitalism and Social Democracy. Cambridge/New York, Cambridge University Press.

; SPRAGUE, John. (1986), Paper Stones: A History of Electoral Socialism. Chicago/London, The University of Chicago Press.

SHELLY, Robert. (1993), "Habermas and the Normative Foundations of a Radical Politics". Thesis Eleven, vol. 35, pp. 62-83.

SKJEI, Erling. (1985), "A Comment on on Performative, Subject, and Proposition in Habermas's Theory of Communication". Inquiry, vol. 28, pp. 87-105.

TARDE, Gabriel. (1901), L'Opinion et la Foule. Paris, Félix Alcan.

TUCKER, Kenneth H. (1996), French Revolutionary Syndicalism and the Public Sphere. Cambridge, Cambridge University Press.

VOIROL, Olivier. (2012), “Teoria Crítica e Pesquisa Social: Da Dialética à Reconstrução”. Tradução de Bruno Simões. Novos Estudos CEBRAP, vol. 93, pp. 81-99.

WENZEL, Harald; HOCHMUTH, Uwe. (1989), “Die Kontingenz von Kommunikation: Zur kritischen Theorie des kommunikativen Handelns von Jürgen Habermas". Kölner Zeitschrift für Soziologie und Sozialpsychologie vol. 41, pp. 241-269.

DADOS - Revista de Ciências Sociais, Rio de Janeiro, vol. 60, n² 2, 2017 
RESUMO

Intersubjetividade ou Solipsismo? Aporias da Teoria do Agir Comunicativo de Jürgen Habermas

Este artigo argumenta que a intersubjetividade pretendida pela teoria do agir comunicativo é solapada pelo solipsismo monológico intrínseco às suas próprias premissas. O fio condutor do artigo é a reflexividade da linguagem (seção I). O problema da intersubjetividade surge na passagem da análise da esfera pública no século XVIII ao paradigma procedimental da democracia deliberativa (seção II). Entre essas extremidades institucionais, Habermas incrusta uma teoria anti-institucional da linguagem, apoiada na "situação ideal de fala" (seção III). A fim de assegurar o engajamento na busca pelo entendimento linguístico, os participantes em um discurso têm de agir de acordo com uma regra de sinceridade (seção IV), o que pressupõe um comprometimento moral prévio e, portanto, monológico, com a busca pelo consenso (seção V). Essas dificuldades comprometem o modelo deliberativo da democracia porque convertem o ideal da simetria discursiva no pressuposto empírico para a deliberação democrática (seção VI).

Palavras-chave: Jürgen Habermas; intersubjetividade; teoria do agir comunicativo; democracia deliberativa; esfera pública

\section{ABSTRACT \\ Intersubjectivity or Solipsism? Problems with Jürgen Habermas' Theory of Communicative Action}

The following article argues that the intersubjectivity claimed by the theory of communicative action is undermined by the monological solipsism intrinsic to the very premises upon which it is based. In terms of structure, the central thread of the article is the reflexivity of the language (section 1). The problem with the intersubjectivity emerges as the article shifts from analyzing the public sphere in the eighteenth century to the procedural paradigm of deliberative democracy (section II). It is between these institutional extremities that Habermas locates his anti-institutional theory of language, supported on the "ideal speech situation" (section III). In the aim of ensuring engagement in the search for linguistic understanding, the participants in a discussion must act according to a rule of sincerity (section IV), which presumes a prior moral commitment (that is therefore monological) to the search for a consensus (section V). Such issues undermine the deliberative model of democracy because they convert the ideal of discursive symmetry into the empirical founding of democratic deliberation (section VI).

Keywords: Jürgen Habermas; intersubjectivity; theory of communicative action; deliberative democracy; public sphere 
RÉSUMÉ

Intersubjectivité ou Solipsisme? Apories de la Théorie de l'Agir Communicationnel de Jürgen Habermas

Cet article suggère que l'intersubjectivité revendiquée par la théorie de l'agir communicationnel se heurte au solipsisme monologique intrinsèque à ses propres prémisses. Le fil conducteur de l'article est la réflexivité du langage (section I). Le problème de l'intersubjectivité surgit lors du passage de l'analyse de la sphère publique au XVIII ${ }^{\mathrm{e}}$ siècle au paradigme procédural de la démocratie délibérative (section II). Entre ces extrémités institutionnelles, Habermas incruste une théorie anti-institutionnelle du langage basée sur la "situation idéale de parole" (section III). Afin d'assurer l'engagement dans la quête de la compréhension linguistique, les participants d'un discours doivent agir en fonction d'une règle de sincérité (section IV), ce qui présuppose un engagement moral préalable et donc monologique visant la recherche du consensus (section V). Ces difficultés compromettent le modèle délibératif de la démocratie en ce qu'elles convertissent l'idéal de la symétrie discursive en présupposé empirique pour la délibération démocratique (section VI).

Mots-clés: Jürgen Habermas; intersubjectivité; théorie de l'agir communicatif; démocratie délibérative; sphère publique

\section{RESUMEN}

¿Intersubjetividad o solipsismo? Aporías de la Teoría de la Acción Comunicativa de Jürgen Habermas

Este artículo argumenta que la intersubjetividad que defiende la teoría de la acción comunicativa se ve solapada por el solipsismo monológico intrínseco a sus propias premisas. El hilo conductor del artículo es la reflexividad del lenguaje (sección I). El problema de la intersubjetividad surge en el paso del análisis de la esfera pública en el siglo XVIII al paradigma procedimental de la democracia deliberativa (sección II). Entre estos extremos institucionales, Habermas incrusta una teoría antinstitucional del lenguaje que se apoya en la "situación ideal del habla" (sección III). A fin de asegurar la implicación en la búsqueda del entendimiento lingüístico, los participantes de un discurso tienen que actuar de acuerdo con una regla de sinceridad (sección IV), lo que presupone un compromiso moral previo y, por tanto, monológico, con la búsqueda del consenso (sección V). Esas dificultades comprometen el modelo deliberativo de la democracia porque convierten el ideal de la simetría discursiva en el presupuesto empírico para la deliberación democrática (sección VI).

Palabras clave: Jürgen Habermas; intersubjetividad; teoría de la acción comunicativa; democracia deliberativa; esfera pública 